\title{
Chapter 2 \\ Voluntary Sustainability Standards and the Sustainable Development Goals
}

\author{
Johannes Blankenbach
}

\section{Introduction}

Voluntary Sustainability Standards (VSS) have since long been used and referred to in the context of the evolving global sustainability and development agenda(s), such as the 1992 Rio Earth Summit's Agenda 21 or the United Nations Millennium Development Goals (MDGs) introduced in 2000. Discussions on the instrumental value of VSS in contributing to global development, however, have gained new ground since the adoption of the Sustainable Development Goals (SDGs) and 2030 Agenda for Sustainable Development in 2015 (UN GA, 2015). More and more VSS schemes and organisations refer to the SDGs in their official communications, ${ }^{1} \mathrm{UN}$ reports point to potential linkages ${ }^{2}$ and while VSS are not explicitly mentioned in the 17 SDGs, 169 targets and 244 indicators, they have made their way into (sub)national SDG implementation strategies. The 2016 Sustainability Strategy of the German State of North Rhine-Westphalia, for instance, includes a target to increase the market share of products labelled as organic (MKULNV, 2016, p. 37). ${ }^{3}$

Can VSS, or in other words, voluntary sets of "criteria defining good social and environmental practices in an industry or product" (ISEAL, 2015), contribute to the implementation of a framework as universal and ambitious as the SDGs? The 2030

\footnotetext{
${ }^{1}$ See, for example, ISEAL and WWF (2017), "How Credible Standards Can Help Companies Deliver the 2030 Agenda"; ISEAL is a VSS umbrella organisation. One of the earliest of such publications came from Fairtrade International (2015) - "Sustainable Development Goals and Fairtrade: The Case for Partnership".

${ }^{2}$ See, for instance, UNFSS (2016), "Meeting Sustainability Goals: Voluntary Sustainability Standards and the Role of the Government".

${ }^{3}$ In an earlier draft of the strategy, the target was to increase the market share of Fairtrade and similarly labelled products; the final version only refers to EU Organic Certification (a public VSS).
}

J. Blankenbach $(\otimes)$

Business \& Human Rights Resource Centre, Berlin, Germany

e-mail: johannes@blankenbach.eu 
Agenda for Sustainable Development is nothing less than an action plan for profound transformation across the globe to improve the lives of all people while keeping the planet healthy (Scholz, 2015, p. 1).

This chapter starts off with a content analysis of VSS, based on data from the International Trade Centre's (ITC) Standards Map, to assess to what extent formal VSS requirements and processes align with the SDGs. Considering that this approach mainly captures what VSS-SDG linkages exist on paper, a subsequent section looks at what kind of real-life contributions VSS may — or may not-make to SDG implementation. This later section also links to the discussion on business and human rights, considering its intersections with the SDGs and VSS debates, respectively. The chapter ends with conclusions from the two substantive sections, including recommendations on the way forward.

\section{Alignment of VSS with the SDGs: Content Analysis}

It is fairly obvious why there has been increasing reference to the link between VSS and SDGs: The conditions that VSS initiatives claim to improve, sometimes even by their very name, all broadly relate to the different dimensions of sustainability. Tying them more systematically to the SDGs, which have gained traction in politics, business, civil society and the broader public in recent years, provides for a compelling narrative and, ideally, greater synergies. The 2030 Agenda also puts much emphasis on the crucial role of business and civil society in promoting sustainable development - two groups of actors that are at least formally represented in many multi-stakeholder VSS initiatives, sometimes along with local producers and public sector actors. The real influence of these different groups within a scheme, of course, varies, depending on how serious it is about multi-stakeholder-and ideally worker-driven - standards design and implementation.VSS also claim to empower consumers to take responsible buying decisions; indeed, two-thirds of VSS use a consumer-facing label, whereas one-third rely on business-to-business implementation (Potts et al., 2014, p. 37). The SDGs are very much in line with a mechanism where, in theory, consumers and end-user companies opt for sustainably produced goods to contribute towards sustainable development in their own countries as well as in other countries along global value chains. This may reflect the paradigm shift from an "aid"-centred development model for the global south (as epitomised by the previous MDGs) towards a more holistic, SDG-based approach, acknowledging global interdependencies and a need for change, especially in richer economies and societies. Whether sustainability in consumption and production as such should just be a voluntary option is of course questionable, all the more so if this option is partly based on a "jungle of certification schemes" (Verzijden, 2017) that, with their multitude, overlaps and gaps, confuse both consumers and companies. In turn, assessments of on-the-ground impacts have, to some extent, remained inconclusive, and certification and verification audits have reportedly failed human and workers' rights (see Sect. 3). 
In a narrow sense, a VSS is a document that lists detailed requirements for good social and environmental practice in business operations. Producers, manufacturers or-depending on the scope of the standard-traders and retailers who wish to become (and stay) certified under a given VSS need to prove that they fulfil these requirements in (usually third-party) certification/verification audits, which in itself is a highly problematic practice (see Sect. 3). However, the assumption is that if VSS are to contribute to SDG implementation, their formal requirements need to correspond to at least some of the SDGs and related targets by addressing similar issues. The ITC Standards Map at www.standardsmap.org (ITC, 2017) provides a viable source for testing this as it details the requirements pertaining to over 210 VSS. From all of these VSS, 16 were included in the formal content analysis in this section, representing the "most important standards initiatives currently active in agriculture, forestry and biofuels sectors with a global reach" according to a landmark review by Potts et al. (2014, p. 3): ${ }^{4}$

- 4C/Global Coffee Platform

- Better Cotton Initiative (BCI)

- Bonsucro

- Cotton made in Africa (CmiA)

- Ethical Tea Partnership (ETP)

- Fairtrade 5

- Forest Stewardship Council (FSC) 6

- International Foundation for Organic Agriculture (IFOAM)

- Programme for the Endorsement of Forest Certification Schemes (PEFC)

- Roundtable on Sustainable Palm Oil (RSPO) ${ }^{7}$

- Sustainable Agriculture Network (SAN)/Rainforest Alliance

- UTZ Certified

- Global Partnership for Good Agricultural Practice (GlobalGAP) ${ }^{8}$

- ProTerra Foundation

- Round Table on Responsible Soy (RTRS)

- Roundtable on Sustainable Biomaterials (RSB)

VSS are not just defined by their requirements but also by corresponding and very distinct formal process criteria for verification, marketing, support, revision and governance. ITC Standards Map features details on some (although not all) of these standards system elements in a separate "processes" section for each VSS in the database. It was therefore possible to complement the analysis of VSS requirements with some information on formal VSS processes. The goal was, as a first step, to

\footnotetext{
${ }^{4}$ Lernoud et al. (2018) also use this sample (apart from ETP and RSB) in an ITC-commissioned assessment of "The State of Sustainable Markets 2018".

${ }^{5}$ Sometimes there are several standards operated by one initiative; this analysis focused on the Fairtrade standard for "small producer organizations".

${ }^{6}$ The formal analysis focused on the FSC standard for "forest management".

${ }^{7}$ The formal analysis focused on RSPO "Principles and Criteria".

${ }^{8}$ The formal analysis focused on the GlobalGAP standard for "crops".
} 
assess whether a specific VSS requirement (e.g. "practices promoting healthy/high nutritional value foods", ITC, 2017) or process criterion fits under one, several or none of the SDGs. ${ }^{9}$

The SDGs, by their very nature, are much broader in scope and wording than the detailed requirements and processes formally established by VSS. In order to proceed without too much of causal interpretation, the 169 SDG targets and 244 SDG indicators (IAEG-SDGs, 2017) ${ }^{10}$ were used to translate the 2030 Agenda's vision into more technical and narrow terms for the purpose of this chapter (with the disadvantage of some aspects of the original SDGs getting lost). It should still be mentioned that matching VSS requirements and processes with corresponding SDGs remains a subjective exercise. Table 1 demonstrates this for a selected goal (SDG 7-Affordable and Clean Energy), listing all categories of VSS requirements and process criteria from the Standards Map that seem to plausibly match it. The on-paper performance of two selected VSS initiatives (ETP and RSPO) in those categories is presented at the right-hand side of the table, as per the 2017 Standards Map data. ${ }^{11}$

Table 1 illustrates the span of causal interpretation that was considered acceptable for establishing plausible formal VSS-SDG correspondences, with the second to last criterion ("responsible entity for implementation cost") probably being the most debatable. The table also shows that one specific requirement or process criterion could be listed only once per SDG at the maximum (but several times across all 17 SDGs, reflecting their interconnectedness). The total results for each SDG were weighted in order to compensate for the different length and complexity of goals. ${ }^{12}$

Turning to the second step of the analysis, i.e. a weighted average of SDG-related VSS requirements and process criteria across all 16 VSS initiatives for each SDG, it is striking to see that VSS, at least on paper, in some or the other way link to all 17

\footnotetext{
${ }^{9}$ The data used for the latest version of this chapter was retrieved from the Standards Map in July/August 2017. There may thus have been updates to formal standards contents in the meantime that were not considered for this analysis.

${ }^{10}$ It is obvious that SDG indicators are not meant to further specify targets in the sense of a guideline for implementation - the purpose of indicators is to measure progress. In fact, however, an indicator integrates key aspects of a target in one very specific, (comparatively) easy-to-measure parameter. The indicator framework therefore provided additional orientation for matching VSS requirements/process criteria with different SDGs (guiding question: "Would implementation of VSS requirement/process criterion $\mathrm{X}$ improve the result of indicator Y?"). In several rounds of testing, targets on their own appeared to be too broad, leaving considerable room for interpretation.

${ }^{11}$ The spreadsheet for all 16 VSS across all 17 SDGs comprises more than 1000 rows.

${ }^{12}$ Some SDGs have very few targets and indicators, whereas others have many. In the latter case, it is easier to find corresponding VSS requirements and process criteria on the Standards Map according to the methodology explained above. This could increase statistical bias (i.e. the more targets/indicators one particular SDG has, the more VSS requirements/process criteria correspond to it). Weighting was applied to reduce such bias, with SDG 7 providing the most extreme example of weighting (coefficient 2.392) as it is the shortest goal in terms of the number of its targets and indicators. Coefficients were determined by dividing the total number of indicators (244) by the number of goals (17); this average was then divided by the number of indicators per SDG to define a weighting coefficient for each SDG, ranging from 0.532 (SDG 3, which has the most indicators) to 2.392 (SDG 7, as explained).
} 
Table 1 Matching of relevant VSS requirements/process criteria from the Standards Map with SDG 7; Checking whether or not $(\boldsymbol{J} / \boldsymbol{X})$ the ETP and RSPO standards include such requirements according to 2017 Standards Map data

\begin{tabular}{l|l|l|l}
\hline $\begin{array}{l}\text { SDG 7 } \\
\text { Targets (7.X) } \\
\text { Indicators (7.X.Y) }\end{array}$ & $\begin{array}{l}\text { Requirements and } \\
\text { process criteria from } \\
\text { Standards Map that } \\
\text { were considered as } \\
\text { matching SDG 7 }\end{array}$ & $\begin{array}{l}\text { Ethical Tea } \\
\text { Partnership (ETP) }\end{array}$ & $\begin{array}{l}\text { Roundtable on } \\
\text { Sustainable Palm Oil } \\
\text { (RSPO) }\end{array}$ \\
\hline $\begin{array}{l}\text { SDG 7: Ensure access to affordable, reliable, } \\
\text { sustainable and modern energy for all }\end{array}$ & $\begin{array}{l}\text { Total: 9.0 } \\
\text { Weighted: 21.5 }\end{array}$ & $\begin{array}{l}\text { Total: 6.0 } \\
\text { Weighted: 14.4 }\end{array}$ \\
\hline
\end{tabular}

7.1. By 2030, ensure universal access to affordable, reliable and modern energy services

\begin{tabular}{l|l|l|l}
\hline $\begin{array}{l}\text { 7.1.1. Proportion of } \\
\text { population with access } \\
\text { to electricity }\end{array}$ & $\begin{array}{l}\text { Services and benefits to } \\
\text { local communities }\end{array}$ & $\boldsymbol{x}$ & $\checkmark$ \\
\cline { 2 - 3 } $\begin{array}{l}\text { Impact assessment on } \\
\text { access to basic services } \\
\text { to local communities }\end{array}$ & $\boldsymbol{x}$ & $\checkmark$ & \\
\hline $\begin{array}{l}\text { 7.1.2. Proportion of } \\
\text { population with } \\
\text { primary reliance on } \\
\text { clean fuels and } \\
\text { technology }\end{array}$ & - & \\
\hline
\end{tabular}

7.2. By 2030, increase substantially the share of renewable energy in the global energy mix

\begin{tabular}{|c|c|c|c|}
\hline \multirow{10}{*}{$\begin{array}{l}\text { 7.2.1. Renewable } \\
\text { energy share in the total } \\
\text { final energy } \\
\text { consumption }\end{array}$} & $\begin{array}{l}\text { Energy use and } \\
\text { management: general } \\
\text { principle }\end{array}$ & $\checkmark$ & $\checkmark$ \\
\hline & $\begin{array}{l}\text { Use of non-renewable } \\
\text { energies: general } \\
\text { principle }\end{array}$ & $\checkmark$ & $\checkmark$ \\
\hline & $\begin{array}{l}\text { Use of alternative } \\
\text { energies including } \\
\text { solar, wind etc. }\end{array}$ & $\checkmark$ & $\checkmark$ \\
\hline & Use of solar energy & $\checkmark$ & $x$ \\
\hline & $\begin{array}{l}\text { Use of hydropower } \\
\text { energy }\end{array}$ & $\checkmark$ & $x$ \\
\hline & Use of wind energy & $\checkmark$ & $x$ \\
\hline & $\begin{array}{l}\text { Use of wood-based } \\
\text { energy }\end{array}$ & $\checkmark$ & $x$ \\
\hline & Use of biofuels & $\checkmark$ & $\checkmark$ \\
\hline & $\begin{array}{l}\text { Criteria relating to the } \\
\text { application of a set of } \\
\text { clean production } \\
\text { practices }\end{array}$ & $x$ & $x$ \\
\hline & $\begin{array}{l}\text { Criteria related to the } \\
\text { storage of energy (incl. } \\
\text { fuel, electricity...) }\end{array}$ & $x$ & $x$ \\
\hline
\end{tabular}


Table 1 (continued)

\begin{tabular}{l|l|l|l}
\hline SDG 7 & $\begin{array}{l}\text { Requirements and } \\
\text { Targets (7.X) } \\
\text { Indicators (7.X.Y) } \text { criteria from } \\
\text { Standards Map that } \\
\text { were considered as } \\
\text { matching SDG 7 }\end{array}$ & $\begin{array}{l}\text { Ethical Tea } \\
\text { Partnership (ETP) }\end{array}$ & $\begin{array}{l}\text { Roundtable on } \\
\text { Sustainable Palm Oil } \\
\text { (RSPO) }\end{array}$ \\
\hline
\end{tabular}

7.3. By 2030, double the global rate of improvement in energy efficiency

\begin{tabular}{l|l|l|l}
\hline $\begin{array}{l}\text { 7.3.1. Energy intensity } \\
\text { measured in terms of } \\
\text { primary energy and } \\
\text { GDP }\end{array}$ & $\begin{array}{l}\text { Reduce use of energy } \\
\text { resources }\end{array}$ & $\checkmark$ & $\boldsymbol{X}$ \\
\hline
\end{tabular}

7.a. By 2030, enhance international cooperation to facilitate access to clean energy research and technology, including renewable energy, energy efficiency and advanced and cleaner fossil-fuel technology, and promote investment in energy infrastructure and clean energy technology

\begin{tabular}{|c|c|c|c|}
\hline \multirow[t]{2}{*}{$\begin{array}{l}\text { 7.a.1. International } \\
\text { financial flows to } \\
\text { developing countries in } \\
\text { support of clean energy } \\
\text { research and } \\
\text { development and } \\
\text { renewable energy } \\
\text { production, including in } \\
\text { hybrid systems }\end{array}$} & $\begin{array}{l}\text { Responsible entity for } \\
\text { implementation cost } \\
\text { (buyer/retailer or the } \\
\text { standard-setting } \\
\text { organisation carries } \\
\text { co-responsibility) (This } \\
\text { criterion was taken } \\
\text { from the "processes" } \\
\text { section of the Standards } \\
\text { Map; all others are } \\
\text { "requirements") }\end{array}$ & $x$ & $x$ \\
\hline & $\begin{array}{l}\text { Criteria related to } \\
\text { access to technology } \\
\text { and innovation }\end{array}$ & $x$ & $x$ \\
\hline
\end{tabular}

7.b. By 2030, expand infrastructure and upgrade technology for supplying modern and sustainable energy services for all in developing countries, in particular least developed countries, small island developing States and landlocked developing countries, in accordance with their respective programmes of support

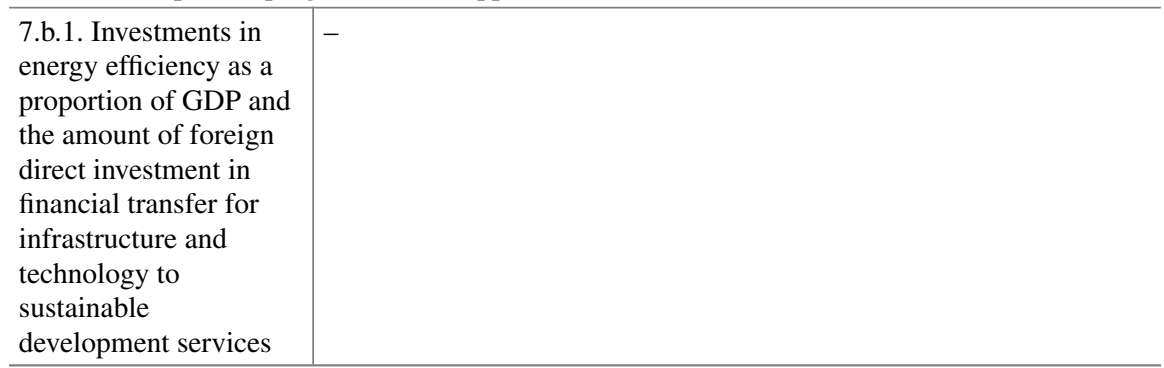

Source Author's compilation based on UN GA (2015), IAEG-SDGs (2017) and ITC (2017) 


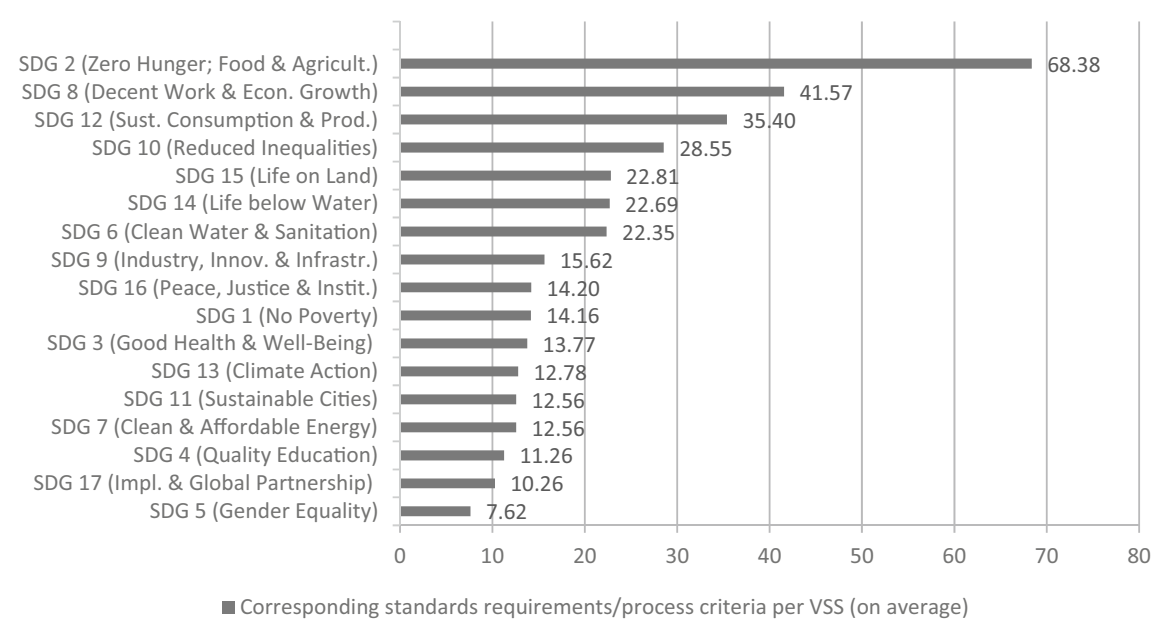

Fig. 1 Average number of standards requirements/process criteria per VSS scheme corresponding to each SDG. Source Author

SDGs (Fig. 1), based on an interpretation of 2017 Standards Map data. On average, the 16 schemes comprehend a significant number of requirements and processes corresponding to each of the SDGs, albeit to varying degrees. For instance, on average, 68.38 formal requirements and process criteria per individual VSS are in line with SDG 2 (Zero Hunger; Food Security \& Sustainable Agriculture), whereas, on average, only 7.62 requirements/process criteria per VSS correspond to SDG 5 (Gender Equality) according to this formal analysis and as shown in the ranking chart in Fig. 1.

SDG 2 (Zero Hunger; Food Security \& Sustainable Agriculture), ${ }^{13}$ SDG 8 (Decent Work \& Economic Growth) and SDG 12 (Sustainable Consumption \& Production) top the ranking, i.e. VSS, on average, list many formal criteria plausibly corresponding to these SDGs (and targets/indicators). This may not come as a surprise as such topics and areas are commonly associated with VSS. SDG 2 comprises relatively broad provisions on productive and sustainable agriculture (targets 2.3, 2.4 and corresponding indicators), which means that many environment-related VSS requirements, e.g. for soil, water and biodiversity conservation as well as for chemicals and waste treatment, plausibly fit under this SDG, along with basic social and economic VSS criteria. However, almost no VSS criteria according to 2017 Standards Map data seem to correspond to the first part of SDG 2, focusing on ending hunger and malnutrition (targets 2.1, 2.2 and corresponding indicators). There are a few VSS out of the sample of 16 that list requirements on "practices promoting healthy/high nutritional value foods" and "avoiding practices endangering food security" (ITC, 2017), but there is nothing beyond this.

\footnotetext{
${ }^{13}$ The full titles of all 17 SDGs can be found in the annex to this chapter.
} 
Regarding SDG 8 (Decent Work \& Economic Growth), many VSS on paper require the abolition of forced and child labour and refer to a wide range of labour rights. These were considered as linked to SDG targets 8.7, 8.8 and their respective indicators. A range of formal VSS criteria on resource efficiency were grouped under target 8.4 and its indicator on material footprints (8.4.1), whereas requirements on wages (e.g. "minimum wage"; ITC, 2017) and gender aspects (e.g. "family-friendly policies to increase the labour force participation of women", ibid.) may formally match target 8.5 and related indicators on full/productive employment.

Regarding SDG 12 (Sustainable Consumption \& Production), number three in the ranking, several formal VSS process criteria on transparent certification/verification practices and annual reporting were considered to match target 12.7 on sustainable public procurement, as such information may support public procurement decisions, provided that VSS are to play a role in this. Most VSS requirements that seem to correspond well to SDG 12 across the 16 reviewed initiatives, however, focus on resource efficiency as well as on chemicals and waste treatment, matching targets 12.2, 12.4 and related indicators. Several gaps remain, even on paper; there are, for instance, no VSS requirements that can be plausibly linked to target 12.3/indicator 12.3.1 on reducing food loss, according to this formal interpretation of Standards Map data from 2017.

While it may not be surprising to find SDG 14 (Life below Water) and SDG 15 (Life on Land) in the medium to upper range of this ranking based on formal VSS content, one may not have expected rank four for SDG 10 (Reduced Inequalities), given its macro-level scope. SDG 10, however, includes some hints as to how microlevel steps may contribute towards transformative change at a larger scale, if truly implemented. For instance, target 10.3 focuses on "eliminating discriminatory laws, policies and practices" (UN GA, 2015). At the level of VSS, requirements relating to "no discrimination at work (ILO, 111)", "minority rights", "involuntary resettlement, physical displacement and/or economic displacement" (ITC, 2017) and other issues may link to this target and indicator. Requirements regarding the "use of price premium" and formal process criteria on sharing certification and implementation costs as well as on access to finance (free of charge) were grouped under target 10.b/indicator 10.b.1 (development assistance and other financial flows). However, only a few of the 16 VSS initiatives under review include such requirements as per 2017 Standards Map data.

There is a clear decline of potential formal VSS-SDG correspondences in the medium to lower range of the chart. SDG 1 (No Poverty), ranked tenth in this theoretical assessment, covers some of the particularly structural and far-reaching issues on the 2030 Agenda. Target 1.2 as well as the corresponding indicators on multidimensional poverty provides some indication of the kind of VSS contents that may be relevant here, ranging from process criteria specifically targeting vulnerable and minority groups to requirements regarding wages, the "hiring [of] workers from local communities" (ITC, 2017) and the promotion of education as well as medical care services. Many VSS initiatives formally list such requirements according to the data on the Standards Map, but as per 2017 data, there are fewer criteria on average 
relating to other dimensions of SDG 1, such as disaster risk reduction and resilience of the poor (target 1.5).

Even this formalistic review of VSS, purely based on content analysis, suggests that VSS in their current shape are poorly suited to contribute towards SDG 4 (Quality Education), SDG 5 (Gender Equality), SDG 7 (Affordable \& Clean Energy), SDG 11 (Sustainable Cities and Communities), SDG 13 (Climate Action) and SDG 17 (Partnerships for the Goals). Very few formal VSS requirements and processes plausibly link to these fields, according to the assessment of 2017 data from the Standards Map.

Last but not the least, relative standard deviations of $44-58 \%$ for SDG 5, SDG 7 and SDG 11 in this formal interpretation of 2017 Standards Map data suggest that some VSS include a larger number of criteria matching these SDGs, whereas other VSS include only a few. Whether or not a VSS initiative has a specific sectoral focus seems to be of low significance in this regard. A comparison between the two forestry VSS under formal review in this section (FSC and PEFC), the two cotton VSS (BCI and CmiA) and the six VSS covering multiple commodities (Fairtrade, IFOAM, SAN/Rainforest Alliance, UTZ Certified, GlobalGAP and ProTerra) produced inconclusive results. Calculations based on this (very small) sample and 2017 Standards Map data suggest that forestry VSS, on average, have the highest number of requirements and process criteria formally corresponding to each of the SDGs, whereas cotton VSS have the lowest. The average numbers for multiple commodity VSS are somewhere in the middle. ${ }^{14}$ The chart below (Fig. 2) illustrates this, using the data for multiple commodity VSS as an orientation value (i.e. the ranking follows the descending order of SDG correspondences per multiple commodity VSS).

\section{From Paper to Practice: Examining VSS Impacts on the Ground}

Even if standards requirements and processes are perfectly in line with the SDGswhich is not always the case, as the previous content analysis has shown-VSS will have anecdotal rather than transformative, and in the worst case, harmful impacts if formal criteria are not properly implemented by producers, processors, manufacturers, traders and/or retailers. All VSS forming part of the formal content analysis in the previous section cover at least the (farm/plantation) level of extraction and production, whereas the processing/manufacturing as well as the trading/retailing levels is covered less frequently, according to Standards Map data from 2017. This in itself might weaken the impact of some initiatives.

Moving beyond the Standards Map sample and turning to VSS impacts in general, it is encouraging to see that, in recent years, VSS impact studies have become more numerous and moved beyond basic facts such as the number of certified producers and the market share of certified products (UNFSS, 2016, p. 2). The socioeconomic

\footnotetext{
${ }^{14}$ The sample for each group, of course, is too small for taking these results at face value.
} 


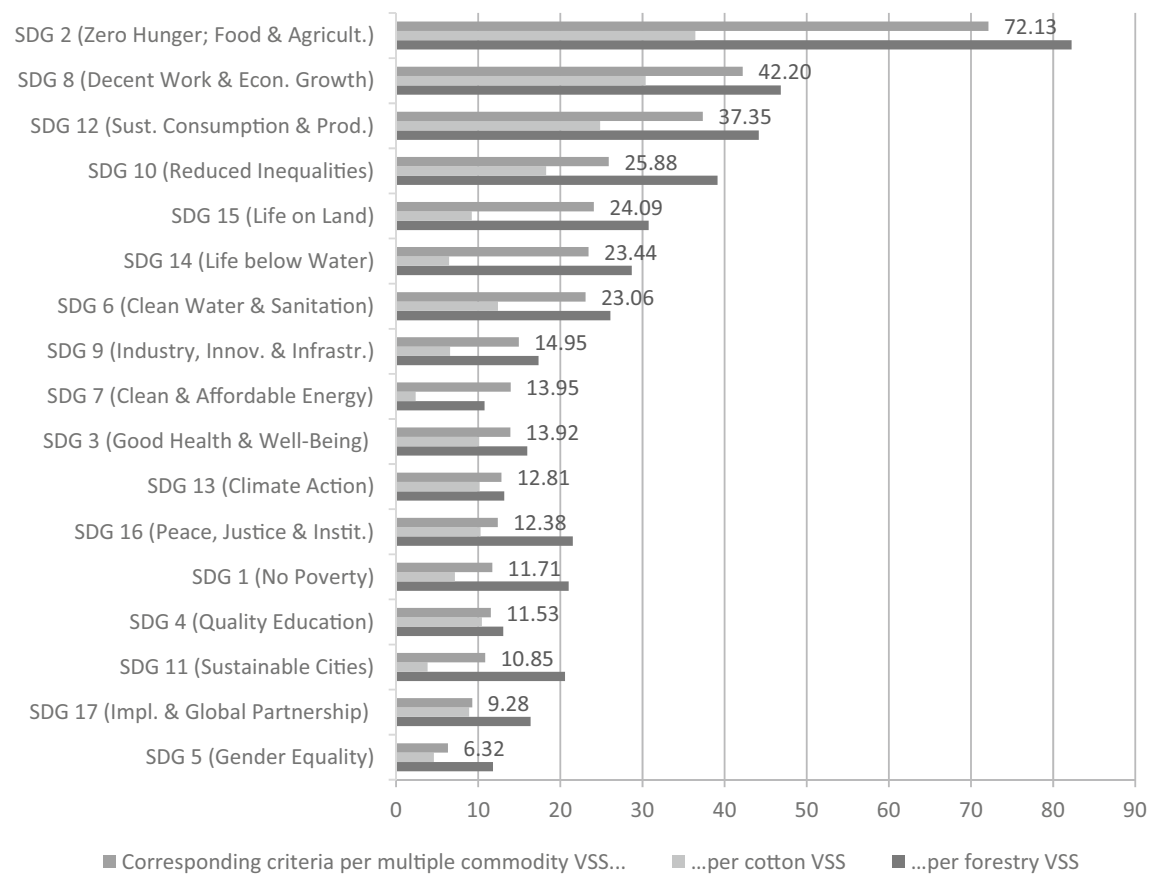

Fig. 2 Comparison of VSS for cotton, forestry products and multiple commodities regarding their average number of requirements/process criteria corresponding to each SDG (for better readability, numbers are only indicated for multiple commodity VSS (upper bar)). Source Author

situation of producers and their communities as well as environmental conditions in the production area are increasingly being covered. This is dearly needed for clarity on whether formal VSS requirements and processes are properly and continuously implemented by producers and other entities covered by a scheme so that it has reallife impacts, as mentioned above. A related question is whether VSS adoption as such really leads to higher sales prices and better market access for those who get certified, and whether poorer, vulnerable producers and their workers and communities can benefit from this as well.

An early broad-based impact assessment conducted by the Committee on Sustainability Assessment (COSA) found moderately positive, though sometimes inconclusive, economic, social and environmental impacts of coffee and cocoa certification in 12 countries at the producer and farm level (COSA, 2013, p. 3). The authors note that in most cases the cost of entry and training for VSS were (partly) covered by external partners such as development agencies, NGOs, buyers and traders, which may no longer be the case once larger numbers of producers aspire certification. COSA is a consortium built on partnerships with numerous organisations, ranging from national and international research institutions to VSS initiatives.

A more recent independent literature review on certification in agriculture finds positive effects of VSS adoption for certified producers and their households with 
regard to prices (plus 14\%), sales income (plus 11\%) and children's schooling (plus $6 \%$ ), but negative effects on workers' wages (minus 13\%), as well as unclear effects regarding yields, household income, wealth and illness, again at the level of producers and their respective households (Oya, Schaefer, Skalidou, McCosker, \& Langer 2017, p. vi). Positive contributions of certification towards "Increased dignity, confidence, control and choice" were found by a Centre for Evaluation/Centrum für Evaluation (CEval) study commissioned by Fairtrade on the scheme's poverty reduction impacts, based on six country and sector case studies with comparative data from 2011/12 and 2017/18. There were also moderate contributions to "improved household income, assets and standards of living", "increased environmental sustainability and resilience to climate change", and "enhanced influence and status of small producers" according to this study, but even less significant effects in four other areas such as "improved access to basic services" (Mauthofer, Schneider, Väth, \& von Cölln, 2018, p. 124).

A synthesis report on agricultural VSS put together by ISEAL, Rainforest Alliance and WWF for their new Evidensia online platform looks at economic criteria in particular (yield, price, costs and income). Only 13 out of 51 studies in this review focus on net household incomes for certified farms. In $31 \%$ of cases, these were higher or significantly higher than for non-certified farms, while in $69 \%$ of cases (nine in absolute numbers), there was no significant difference (Evidensia, 2019, p. 18).

Several VSS assessments have focused on potential environmental contributions, such as a recent synthesis report on conservation outcomes, compiled by the Meridian Institute. A section based on seven different studies states that the adoption of certification reduced deforestation rates in some settings, specifically Ethiopia and Colombia as well as primary forests in Indonesia (Komives et al., 2018, p. 4).There was no reported difference between certified and non-certified areas in other settings, however. Impacts on plant diversity were generally found to be positive and impacts on fauna diversity mixed, again based on a very small sample of five studies covering plant and three covering fauna biodiversity (ibid., p. 18).

The clearest positive income and, based on fewer examples, environmental effects seem to relate to the adoption of "organic" standards in farming, as production costs and yields tend to be similar to conventional production (or even more favourable) while sales prices are higher, according to a number of recent impact studies. This leads to higher profits and/or household income for farmers (but not necessarily for their workers, who are not specifically looked at) across different commodity and country samples such as rice from northern India (Eyhorn, van den Berg, Dedock, Maat, \& Srivastava, 2018), strawberries from central Brazil (Resende Filho et al., 2017) and tea from northern Vietnam (Doanh, Thuong, \& Heo, 2018). As for these three reports, two of them do not specify under what type of scheme organic farms were certified. The India case study of smallholder farmers in hilly Uttarakhand mentions Indian and Swiss standards as well as EU Council Regulation (EC) No. 834/2007, which is about the EU's public organic VSS scheme and has a predominantly agricultural and technical focus. Apart from higher profits for local producers due to less inputs and higher yields and sales prices, this study found that organic 
management improved soil quality and helped save irrigation water. What is interesting about the Uttarakhand case is the role of one Indian processing company, Nature Bio-Foods Ltd., business partner of Swiss retailer Coop, in providing farmers with organic seeds and biofertiliser at cost prices. The company also paid for participating farmers' third-party certification against the aforementioned organic standards, as well as for additional Fairtrade certification, and purchased the certified paddy for an agreed (Fairtrade) price plus an organic premium of 10-15\%.

Without such company engagement, potential transformative impacts of VSS schemes may be hampered by their lack of accessibility for poorer producers, especially smallholders, who are in the most urgent need of livelihood gains but struggle with high certification and implementation costs, among other challenges. In many cases, the bulk of the certification benefits may thus have gone to larger, betterorganised producers in regions with higher production capacities, as well as to traders, brands and retailers (UNFSS, 2016, p. 4). What possibly reinforces this pattern is that real price premiums for producers of certified goods still largely depend on external (market) factors, i.e. whether buyers are willing to pay a higher price. What seems to work well for organic farming may work less well for other forms of certification. Only three out of 16 VSS in the sample used in the previous section include a formal internal requirement of price premiums, according to the Standards Map as per 2017 data. Carlson and Palmer (2016, pp. 130-132), focusing on the "less tangible benefits of certification", point to the general unwillingness of powerful retailers to pay a premium to suppliers.

Other work more specifically addresses the social impacts of VSS adoption, such as an independent study by the School of Oriental and African Studies (SOAS), University of London, from 2014 on VSS implementation in Uganda and Ethiopia. It contends that research on Fairtrade standards has so far overly focused on the small farm household using family labour, rather than looking at the plight of seasonal and casual agricultural wage workers (Cramer, Johnston, Oya, \& Sender, 2014, pp. 20 22). Considering the scope of other studies, there seems to be a general need to look beyond the level of producers and smallholders to uncover the situation of their workers and/or domestic servants, who may be much worse off. Indeed, the poor wages and labour conditions of workers covered by the SOAS sample did not improve under certification, according to the study (ibid., p. 15).

A growing body of evidence-based academic and NGO research has also pointed to the failures of social auditing, a practice that is part of virtually every VSS scheme, in capturing abuses of the human rights of workers and communities in global value chains. ${ }^{15}$ The European Centre for Constitutional and Human Rights (ECCHR, 2018), for instance, comments on the Ali Enterprises fire in a supplier factory in Karachi, Pakistan: "Th[e...] audit failed to notice a range of infractions on the international standards it was upholding (SA 8000) and Pakistani safety standards regulations that would prove fatal, including an illegally constructed floor,

\footnotetext{
${ }^{15}$ See the Business \& Human Rights Resource Centre's web portal and blog series on "Beyond Social Auditing" at https://www.business-humanrights.org/en/beyond-social-auditing.
} 
and defunct fire alarm system, as well as the presence of child labour and structural excessive overtime". ${ }^{16}$ A research report on forced labour risks in cocoa supply chains in Ghana and tea supply chains in India, based on, inter alia, in-depth interviews with more than 120 tea and cocoa workers and a survey of over 1000 tea and cocoa workers, states: "Some of the worst cases of exploitation documented within our research occurred on ethically certified [tea] plantations" (LeBaron, 2018, p. 3).

Auditors, in many cases from a formally independent third-party, certify and verify standards compliance at the supplier level, which is then cited by end-user companies and big brands, but the system is unreliable for a number of reasons. Audit firms may be subject to market pressures and compete for clients, for instance; there is a clear conflict of interest if the cost of certification is met by the entity that is audited, e.g. a supplier farm or factory. A recent Guardian report on migrant worker exploitation at tomato farms in southern Italy quotes an NGO worker arguing that "[w]hen the person being inspected is the same person paying the inspector's fee, 99.9\% of the time the inspector will say: "No, you're not exploiting anyone'" (Jones $\&$ Awokoya, 2019). Also, audits may just require "checklist compliance" (Terwindt $\&$ Burckhardt, 2018), miss out on contextual factors ranging from building safety to religious discrimination, or proceed without an on-site visit, as alleged in the Ali Enterprises case (ECCHR, 2018). The Guardian report on tomato farming in the Italian south found certification bodies to "perform an arm's-length box-ticking exercise, and [to] rarely visit the farms" (Jones \& Awokoya, 2019). There are also accounts of business owners literally cheating on auditors and telling their workers to change working practices while the audit is ongoing (LeBaron, 2018, p. 41).

Engagement with workers, who could point to shortcomings if there were appropriate and safe arrangements for them to speak out, remains low or superficial. For instance, the tea and cocoa research mentioned above found that $95 \%$ of surveyed workers on Ghanaian cocoa plantations were unaware whether they were working on a certified site (LeBaron, 2018, p. 42). All this has led critics to argue that "these programs mask significant risks for workers at the bottom and brands atop global supply chains", and that voluntary certification is "part of the problem, not the solution" (WSR Network, 2018, p. 3). The trend of VSS achieving more and more significant market shares in individual commodities such as coffee, cocoa and tea ${ }^{17}$ (Lernoud et al., 2018, p. 4) is thus not as good news as it potentially could be.

The growing evidence of human rights risks and abuses going unnoticed by social audits, including VSS certification and verification audits, should also inform the debate on SDG implementation, as SDGs "seek to realise the human rights of all" according to the 2030 Agenda (UN GA 2015, p. 1). A study by the Danish Institute for Human Rights (DIHR) claims that more than $90 \%$ of the SDG targets are linked

\footnotetext{
${ }^{16}$ See the Business \& Human Rights Resource Centre's coverage of an OECD complaint filed by NGOs against auditing firm RINA, including RINA's response, at https://www.business-humanr ights.org/en/ngo-coalition-files-oecd-complaint-with-italian-ncp-against-auditor-rina-for-allege dly-failing-to-detect-safety-labour-abuses-at-ali-enterprises-factory-in-pakistan-incl-co.

${ }^{17}$ According to the 2018 "State of Sustainability Markets" report (Lernoud et al., 2018, p. 4), at least $25.8 \%$ of global coffee area, $22.8 \%$ of global cocoa area and $13.2 \%$ of global tea area are certified.
} 
to core international human rights and labour standards (Filskov \& Feiring, 2018, p. 1). VSS content analysis in the previous section has shown that many human and labour rights are explicitly listed as formal VSS requirements. As long as certification and verification audits, however, miss out on rights abuses, the practical value of such requirements remains limited.

Human rights due diligence, as established by the UN Guiding Principles on Business and Human Rights (UNGPs; OHCHR, 2011), has emerged as a central and practicable concept specifying companies' responsibilities in respecting human rights across all their operations and global value chains. Due diligence is about them "assessing actual and potential human rights impacts, integrating and acting upon the findings, tracking responses, and communicating how impacts are addressed" (ibid., p. 17), all in close collaboration with those potentially or actually affected by negative human rights impacts. Another recent discussion paper put forward by the DIHR argues "that the implementation of the UNGPs can be the single-most important contribution by business to the realisation of the SDGs" (Morris, Wrzoncki, \& Lysgaard, 2019, p. 9), and thus to real transformations of the status quo.

In order for human rights due diligence to be effective, companies need to internalise due diligence steps rather than outsourcing them to an external scheme. This makes all the more sense as the kind of price and time pressure exerted by many big brands is said to have been driving worker exploitation at the supplier level, e.g. in the garment (HRW, 2019) and food (Jones \& Awokoya, 2019) sectors. The Organization for Economic Co-operation and Development's (OECD) Due Diligence Guidance for Responsible Business Conduct, providing practical orientation for companies on how human rights due diligence can be implemented, states that "[p]articipation in an initiative does not shift responsibility from the enterprise to the initiative for adverse impacts that it causes, contributes to or to which it is directly linked" (OECD, 2018, p. 53). Questions of responsibility can become questions of legal liability once human rights due diligence becomes part of binding regulation. ${ }^{18}$ Pioneering legislative examples such as the French Duty of Vigilance Law are not limited to human rights as they legally mandate respect for human rights and the environment into business activities (ECCJ, 2017, p. 1), thus having considerable transformative power in line with the SDGs. What role VSS initiatives in their current shape can play in this context is questionable, given their shortcomings in uncovering and mitigating abuse. If they are to play a role in supporting — not replacing-companies' human rights and environmental due diligence, they will, among other steps, have to further align VSS requirements with human rights (and thus with the SDGs, as the two areas are so closely linked), i.e. at least with those expressed in the International Bill of Human Rights and the ILO's core/fundamental Conventions. Most importantly, however, the role of workers and other rights-holders in standards design, governance, implementation and assurance needs to be strengthened.

\footnotetext{
${ }^{18}$ See the Business \& Human Rights Resource Centre's web portal and blog series on "Mandatory Due Diligence" at https://www.business-humanrights.org/en/mandatory-due-diligence.
} 


\section{Conclusions and Recommendations}

To conclude, VSS, in theory, link to the SDGs in many ways, but there are practical constraints regarding their transformative impacts and on-the-ground contributions towards SDG implementation. As long as voluntary certification provides a fig leaf for perpetuated human rights abuse in global value chains that goes unnoticed due to unreliable audits, it is at least in some contexts part of the problem rather than the solution.

At a formal level, a semi-statistical analysis of Standards Map data from 2017 in this chapter pointed to various correspondences between VSS criteria and the 17 SDGs (Fig. 1), suggesting that the detailed requirements of many VSS cover different aspects of the 2030 Agenda. There are areas with less alignment, however, such as poverty reduction, climate change, health as well as gender, where VSS are thin on concrete requirements even on paper. Most of these issues, like many others covered by the SDGs, directly relate to human rights.

Regarding on-the-ground impacts, the increasing number and quality of impact studies is good news. Some of them have been commissioned or co-authored by individual schemes or related organisations, which could pose a credibility problem, but this was not further explored here. Most studies so far have found modest or inconclusive sustainable development impacts in the context of VSS adoption. Improvements of social, environmental and economic indicators may be relatively difficult to measure in some contexts, but there also seems to be an indication that formal requirements are often inadequately implemented by those getting certified, and/or that there is a lack of tangible certification benefits, such as higher sales prices and better market access. What is even more disturbing is the number of documented cases of social audit failure, including in the context of certification. Conditions such as those reported for some cocoa and tea plantations by LeBaron (2018), or in Jones' and Awokoya's (2019) Guardian feature on Italian tomato farms, as well as in many other reports, raise serious doubts as to whether VSS schemes and the audits they require can reliably uncover and mitigate human and labour rights abuses. If these shortcomings cannot be resolved, this will severely hamper the transformative potential and impacts of VSS initiatives, given the mutually reinforcing relationship between human rights and the SDGs.

As VSS seem to be there to stay, however, governments, businesses and civil society should engage with each other, and with standards organisations, to explore and maximise any potential "common good" benefits of certification while mitigating deficiencies and pitfalls and promoting alternatives, including regulation.

- With corporate due diligence on human rights and the environment emerging as the global standard of practice for responsible business conduct in line with human rights obligations and the SDGs, there should be an open an honest debate on what role VSS schemes can-or cannot-play in this context, and whether and how they can be adapted. It is crucial to recognise that prime responsibility for human rights and environmental due diligence across a company's global value chains is with the company, to avoid situations where no one feels-and 
can be held-accountable. Arguably, many businesses willing to improve respect for human rights and the environment have relied too heavily on external initiatives, including VSS, which then have not always delivered what they (seemed to) promise, especially when it comes to failures in uncovering human rights abuse through certification and verification audits. VSS schemes should state clearly what their limitations are, and companies should be clear about this and internalise human rights and environmental due diligence, effectively integrating it into all their operations rather than outsourcing it. There may be ways in which fundamentally reformed VSS schemes can support—not replace-this, e.g. by helping companies engage with local players and rights-holders, provided that the initiative itself manages to step up its worker engagement and establishes trustful NGO relations on the ground. This includes accessible complaints and grievance mechanisms where whistle-blowers and victims of abuse can speak out without fear of reprisals, including sub-contracted or casual workers and surrounding communities. At a formal level, VSS schemes should further align their requirements with all human rights, which will also strengthen their alignment with the SDGs as there are strong interconnections. At a practical level, they should substantially improve the reliability and independence of certification and verification audits, introduce additional checks, and publish audit results, including negative results. Most importantly, the influence of workers and other local rights-holders in standards design, governance, implementation and assurance needs to be credibly strengthened.

- VSS organisations, academia, civil society and governments could explore opportunities for integrated sustainable development impact monitoring of VSS and SDG implementation attempts, making use of and strengthening current global efforts on statistical capacity and better availability of sustainable development data. The Cape Town Global Action Plan for Sustainable Development Data acknowledges that "[e]ffective planning, follow-up and review of the implementation of the 2030 Agenda for Sustainable Development requires the collection, processing, analysis and dissemination of an unprecedented amount of data and statistics at local, national, regional and global levels and by multiple stakeholders" (HLG-PCCB, 2017, p. 1). Matching SDG monitoring results with data on VSS adoption in a specific region or district may provide cost-efficient opportunities for continuous impact monitoring at an unprecedented scale. For improved development impacts and human rights compliance, the issue of price premiums secured by the standards system (e.g. through a fund supported by end-user companies) is of utmost importance as well as requirements on fair purchasing practices by lead firms and living wages along their value chains that are actually monitored and implemented, including for wage and casual workers in smallholder production. Progress on these and any other human rights- and environment-related matters cannot be left to voluntary initiatives alone, however, but requires effective mandatory due diligence regulation for companies, among other measures.

- Governments should support independent VSS impact assessments and surveys that also look at auditing practices, conducted by leading academics in collaboration with workers and other rights-holders. Governments should also promote 
"standards for standards" at national and international levels, including mandatory legal requirements, e.g. on audit transparency and auditor liability, to guide and harmonise fundamental reforms of VSS requirements, processes, and most importantly, implementation and assurance. National platforms on sustainability standards, connected to one another through a global "platform of platforms" such as the UN Forum on Sustainability Standards (UNFSS), represent one low-barrier option to bridge coordination gaps, to harmonise the plethora of standards, and to increase local ownership. The Indian government launched such a platform supported by the UNFSS in 2016 already, mandating the autonomous Quality Council of India (QCI) to host its secretariat. Similarly, the Brazilian, Chinese and Mexican governments co-founded sustainbility standards platforms with support from the UNFSS. Platforms should now ensure proper worker and rights-holder engagement and also explore legislative options.

- Considering that the SDGs build on human rights, and that corporate human rights and environmental due diligence potentially represents the single-most important business contribution to sustainable development, governments should promote mandatory due diligence regulation at the national, regional and global (UN) level. Such regulation needs to make clear that prime responsibility for due diligence lies with the company, and that therefore, external initiatives cannot replace but at best support it, if fundamentally reformed.

\section{Annex}

\section{Sustainable Development Goals}

Goal 1. End poverty in all its forms everywhere

Goal 2. End hunger, achieve food security and improved nutrition and promote sustainable agriculture

Goal 3. Ensure healthy lives and promote well-being for all at all ages

Goal 4. Ensure inclusive and equitable quality education and promote lifelong learning opportunities for all

Goal 5. Achieve gender equality and empower all women and girls

Goal 6. Ensure availability and sustainable management of water and sanitation for all

Goal 7. Ensure access to affordable, reliable, sustainable and modern energy for all

Goal 8. Promote sustained, inclusive and sustainable economic growth, full and productive employment and decent work for all

Goal 9. Build resilient infrastructure, promote inclusive and sustainable industrialisation and foster innovation

Goal 10. Reduce inequality within and among countries

Goal 11. Make cities and human settlements inclusive, safe, resilient and sustainable 
Goal 12. Ensure sustainable consumption and production patterns

Goal 13. Take urgent action to combat climate change and its impacts*

Goal 14. Conserve and sustainably use the oceans, seas and marine resources for sustainable development

Goal 15. Protect, restore and promote sustainable use of terrestrial ecosystems, sustainably manage forests, combat desertification, and halt and reverse land degradation and halt biodiversity loss

Goal 16. Promote peaceful and inclusive societies for sustainable development, provide access to justice for all and build effective, accountable and inclusive institutions at all levels

Goal 17. Strengthen the means of implementation and revitalise the global partnership for sustainable development

*Acknowledging that the United Nations Framework Convention on Climate Change is the primary international, intergovernmental forum for negotiating the global response to climate change.

\section{References}

Carlson, A., \& Palmer, Ch. (2016). A qualitative meta-synthesis of the benefits of eco-labeling in developing countries. Ecological Economics, 127, 129-145. https://doi.org/10.1016/j.ecolecon. 2016.03.020.

COSA (Committee on Sustainability Assessment). (2013). The COSA measuring sustainability report: Coffee and cocoa in 12 countries. Retrieved from http://thecosa.org/wp-content/uploads/ 2014/01/The-COSA-Measuring-Sustainability-Report.pdf.

Cramer, C., Johnston, D., Oya, C., \& Sender, J. (2014). Fairtrade, employment and poverty reduction in Ethiopia and Uganda. London: School of Oriental and African Studies (SOAS). Retrieved from http://ftepr.org/wp-content/uploads/FTEPR-Final-Report-19-May-2014-FINAL.pdf.

Doanh, N. K., Thuong, N. T. T., \& Heo, Y. (2018). Impact of conversion to organic tea cultivation on household income in the mountainous areas of Northern Vietnam. Sustainability, 2018(10), 4475. https://doi.org/10.3390/su10124475.

ECCHR (European Centre for Constitutional and Human Rights). (2018). OECD complaint against Italian auditor RINA. Retrieved from https://www.business-humanrights.org/en/ngo-coa lition-files-oecd-complaint-with-italian-ncp-against-auditor-rina-for-allegedly-failing-to-detectsafety-labour-abuses-at-ali-enterprises-factory-in-pakistan-incl-co.

ECCJ (European Coalition for Corporate Justice). (2017). French corporate duty of vigilance law: frequently asked questions. Brussels: Author. Retrieved from http://corporatejustice.org/docume nts/publications/french-corporate-duty-of-vigilance-law-faq.pdf.

Evidensia. (2019). Effects of voluntary sustainability standards on yield, price, costs and income in the agriculture sector. London: ISEAL Alliance. Retrieved from https://www.evidensia.eco/res ources/188/.

Eyhorn, F., van den Berg, M., Dedock, C., Maat, H., \& Srivastava, A. (2018). Does organic farming provide a viable alternative for smallholder rice farmers in India? Sustainability, 2018(10), 4424. https://doi.org/10.3390/su10124424.

Fairtrade. (2015). Sustainable development goals and Fairtrade: The case for partnership. Retrieved from http://www.fairtrade.net/fileadmin/user_upload/content/2009/resources/15-10_ Sustainable_Development_Report.pdf. 
HLG-PCCB (High-Level Group for Partnership, Coordination and Capacity-Building for Statistics for the 2030 Agenda for Sustainable Development). (2017). Cape Town global action plan for sustainable development data. Retrieved January 15, 2017 from http://unstats.un.org/sdgs/files/ global-consultation-hlg-1/GAP_HLG-20161021.pdf.

HRW (Human Rights Watch). (2019). Paying for a bus ticket and expecting to fly. In How apparel brand purchasing practices drive labor abuses. Retrieved from https://www.hrw.org/sites/def ault/files/report_pdf/wrd0419_web2.pdf.

IAEG-SDGs (Inter-agency Expert Group on SDG Indicators). (2017). Revised list of global sustainable development goal indicators. Retrieved from https://unstats.un.org/sdgs/indicators/indica tors-list/.

ISEAL (International Social and Environmental Accreditation and Labelling Alliance). (2015). What is a sustainability standard? Retrieved from http://www.isealalliance.org/waypoint/whatis-a-sustainability-standard.

ISEAL/WWF (World Wildlife Fund). (2017). How credible standards can help companies deliver the 2030 agenda. Retrieved from http://d2ouvy59p0dg6k.cloudfront.net/downloads/wwf_iseal_ sdg_2017.pdf.

ITC (International Trade Centre). (2017). Standards map. Retrieved from http://standardsmap.org/. Jones, T., \& Awokoya, A. (2019). Are your tinned tomatoes picked by slave labour? The Guardian. Retrieved from https://www.theguardian.com/world/2019/jun/20/tomatoes-italy-mafia-migrantlabour-modern-slavery.

Komives, K., Arton, A., Baker, E., Kennedy, E., Longo, C., Newsom, D., ...Romero, C. (2018). How has our understanding of the conservation impacts of voluntary sustainability standards changed since the 2012 publication of "Toward sustainability: The roles and limitations of certification?" Washington, DC: Meridian Institute. Retrieved from https://merid.org/content/projects/supply_ chain_sustainability_research_fund.

LeBaron, G. (2018). The global business of forced labour. Report of Findings. Sheffield: SPERI \& University of Sheffield. Retrieved from http://globalbusinessofforcedlabour.ac.uk/report/.

Lernoud J., Potts, J., Sampson, G., Schlatter, B., Huppe, G., Voora, V., ... Dang, D. (2018). The state of sustainable markets 2018: Statistics and emerging trends. Geneva: International Trade Centre (ITC). Retrieved from http://www.intracen.org/uploadedFiles/intracenorg/Content/Public ations/Sustainibility\%202018\%20layout-FIN-web-v1.pdf.

Mauthofer, T., Schneider, E., Väth, S.J., \& von Cölln, F. (2018). Assessing the impact of Fairtrade on poverty reduction through rural development (Follow up study). Saarbrücken: CEval. Retrieved from https://www.evidensia.eco/resources/431/.

MKULNV (Ministry for Climate Protection, Environment, Agriculture, Nature and Consumer Protection). (2016). Sustainability strategy for North Rhine-Westphalia. Düsseldorf: Author. Retrieved from https://www.nachhaltigkeit.nrw.de/fileadmin/download/sustainability_strategy_ for_north_rhine-westphalia.pdf.

Morris, D., Wrzoncki, E., \& Lysgaard S. A. (2019). Responsible business conduct as a cornerstone of the 2030 Agenda-A look at the implications. Copenhagen: The Danish Institute for Human Rights. Retrieved from https://www.humanrights.dk/sites/humanrights.dk/files/media/dokume nter/udgivelser/hrb_2019/responsible_business_conduct_as_a_cornerstone_of_the_2030_a genda_dihr_2019.pdf.

Filskov, N., \& Feiring, B. (2018). Human Rights and the 2030 agenda for sustainable development: Lessons learned and next steps. Copenhagen: The Danish Institute for Human Rights. Retrieved from https://www.humanrights.dk/sites/humanrights.dk/files/media/dokumenter/sdg/ hr_and_2030_agenda-web_2018.pdf.

OECD (Organisation for Economic Co-operation and Development). (2018). OECD due diligence guidance for responsible business conduct. Paris: Author. Retrieved from http://mneguidelines. oecd.org/OECD-Due-Diligence-Guidance-for-Responsible-Business-Conduct.pdf.

OHCHR (Office of the High Commissioner for Human Rights). (2011). Guiding principles on business and Human Rights. Geneva: Author. Retrieved from https://www.ohchr.org/documents/ publications/GuidingprinciplesBusinesshr_eN.pdf. 
Oya, C., Schaefer, F., Skalidou, D., McCosker, C., \& Langer, L. (2017). Effects of certification schemes for agricultural production on socio-economic outcomes in low-and middleincome countries: A systematic review. London: International Initiative for Impact Evaluation (3IE). Retrieved from https://www.3ieimpact.org/evidence-hub/publications/systematic-reviewsummaries/effectiveness-agricultural-certification.

Potts, J., Lynch, M., Wilkings, A., Huppé, G., Cunningham, M., \&Voora, V. (2014). The state of sustainability initiatives review 2014: Standards and the green economy: state of sustainability initiatives. Winnipeg/London: International Institute for Sustainable Development (IISD)/ International Institute for Environment and Development (IIED). Retrieved from https://www.iisd. org/pdf/2014/ssi_2014.pdf.

Resende Filho, M. A., Andow, D. A., Carneiro, R. G., Lorena, D. R., Sujit, E. R., \& Alves, R. T. (2017). Economic and productivity incentives to produce organically in Brazil. Evidence from strawberry production in the Federal District. Working paper. Retrieved from https://www.res earchgate.net/publication/311582588_Economic_and_productivity_incentives_to_produce_org anically_in_Brazil_Evidence_from_strawberry_production_in_the_Federal_District.

Scholz, I. (2015). Introduction: A universal agenda for sustainable development and global cooperation. In M. Loewe \& N. Rippin (Eds.), Translating an ambitious vision into global transformation: the 2030 agenda for sustainable development (pp. 1-9). DIE Discussion Paper 7/2015. Retrieved from http://www.die-gdi.de/uploads/media/DP_7.2015_NEU2_11.pdf.

Terwindt, C. \& Burckhardt, G. (2018). Social audits in the textile industry: How to control the controllers? Retrieved from https://www.business-humanrights.org/en/social-audits-in-thetextile-industry-how-to-control-the-controllers.

UNFSS (UN Forum on Sustainability Standards). (2016). Meeting sustainability goals: voluntary sustainability standards and the role of the government. 2nd Flagship Report. Geneva: Author. Retrieved from https://unfss.files.wordpress.com/2016/09/final_unfss-report_28092016.pdf.

UN GA (United Nations General Assembly). (2015). Transforming our world: the 2030 Agenda for sustainable development. New York: Author. Retrieved from http://www.un.org/ga/search/ view_doc.asp?symbol=A/RES/70/1\&Lang=E.

Verzijden, K. (2017). A guide to the Dutch sustainable certification jungle in food. Amsterdam: AXON. Retrieved from https://www.axonlawyers.com/a-guide-to-the-dutch-sustainable-certif ication-jungle-in-food/.

WSR Network (Worker-Driven Social Responsibility Network). (2018). Certification $\neq$ Enforcement. Retrieved from https://wsr-network.org/wp-content/uploads/2018/08/WSR_Certif ication\%CC\%B8Enforcement.pdf.

Open Access This chapter is licensed under the terms of the Creative Commons Attribution 4.0 International License (http://creativecommons.org/licenses/by/4.0/), which permits use, sharing, adaptation, distribution and reproduction in any medium or format, as long as you give appropriate credit to the original author(s) and the source, provide a link to the Creative Commons license and indicate if changes were made.

The images or other third party material in this chapter are included in the chapter's Creative Commons license, unless indicated otherwise in a credit line to the material. If material is not included in the chapter's Creative Commons license and your intended use is not permitted by statutory regulation or exceeds the permitted use, you will need to obtain permission directly from the copyright holder.

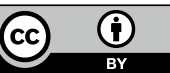

